Article

\title{
Evaluating Atmospheric Pollutants from Urban Buses under Real-World Conditions: Implications of the Main Public Transport Mode in São Paulo, Brazil
}

\author{
Thiago Nogueira ${ }^{1,2, *, \dagger}$, Pamela A. Dominutti ${ }^{1,3, *,+} \mathbb{C}$, Marcelo Vieira-Filho ${ }^{4}$, \\ Adalgiza Fornaro ${ }^{1}$ (I) and Maria de Fatima Andrade ${ }^{1}$ \\ 1 Departamento de Ciências Atmosféricas-Instituto de Astronomia, Geofísica e Ciências Atmosféricas-IAG. \\ Universidade de São Paulo, São Paulo 05508-090, Brazil; adalgiza.fornaro@iag.usp.br (A.F.); \\ maria.andrade@iag.usp.br (M.d.F.A.) \\ 2 Departamento de Saúde Ambiental - Faculdade de Saúde Pública. Universidade de São Paulo, \\ São Paulo 01246-904, Brazil \\ 3 Wolfson Atmospheric Chemistry Laboratories, Department of Chemistry, University of York, \\ York YO10 5DD, UK \\ 4 Departamento de Recursos Hídricos e Saneamento, Universidade Federal de Lavras, \\ Lavras 37200-000, Brazil; marcelo.filho@ufla.br \\ * Correspondence: thiago.nogueira@iag.usp.br (T.N.); pamela.dominutti@york.ac.uk (P.A.D.) \\ + These authors contributed equally to this work.
}

Received: 30 January 2019; Accepted: 11 February 2019; Published: 1 March 2019 updates

\begin{abstract}
The broad expanse of the urban metropolitan area of São Paulo (MASP) has made buses, the predominant public transport mode for commuters in the city. In 2016, the bus fleet in the MASP reached 56,354 buses and it was responsible for more than 12 million daily trips. Here, we evaluate for the first time, the emission profile of gaseous and particulate pollutants from buses running on $7 \%$ biodiesel $+93 \%$ petroleum diesel and their spatial distribution in the MASP. This novel study, based on four bus terminal experiments, provides an extensive analysis of atmospheric pollutants of interest to public health and climate changes, such as $\mathrm{CO}_{2}, \mathrm{CO}, \mathrm{NOx}, \mathrm{VOCs}, \mathrm{PM}_{10}, \mathrm{PM}_{2.5}$ and their constituents (black carbon (BC) and elements). Our results suggest that the renovation of the bus fleet from Euro II to Euro V and the incorporation of electric buses had a noticeable impact (by a factor of up to three) on the $\mathrm{CO}_{2}$ emissions and caused a decrease in $\mathrm{NO}$ emissions, by a factor of four to five. In addition, a comparison with previous Brazilian studies, shows that the newer bus fleet in the MASP emits fewer particles. Emissions from the public transport sector have implications for public health and air quality, not only by introducing reactive pollutants into the atmosphere but also by exposing the commuters to harmful concentrations. Our findings make a relevant contribution to the understanding of emissions from diesel-powered buses and about the impact of these new vehicular technologies on the air quality in the MASP.
\end{abstract}

Keywords: air quality; biodiesel; bus; metal; vehicular emissions; direct emissions

\section{Introduction}

In 2015, pollution was responsible for $16 \%$ of all premature deaths worldwide. Atmospheric pollutants, in particular, have been responsible for the deaths of more than four million people [1]. In the metropolitan area of Sao Paulo (MASP) several studies had analyzed the impacts of air pollution on human health. The findings reported that about ten thousand deaths per year are associated with air pollution in the MASP [2,3]. Although the road transport sector has been responsible for air quality degradation in urban areas, the public transit sector can be an essential agent in the control of emissions, mainly by using 
alternative fuels and more current bus engines [4]. Commuters are exposed to air pollution in different ways, depending on the mode of transport, the position of the commuter in relation to the pollutant concentration gradients, and the microenvironmental conditions for pollutant dispersion [5].

In addition to gaseous pollutants, the concentrations of particulate matter (PM) in the atmosphere, mainly fine PM ( $\left.\mathrm{PM}_{2.5}\right)$, have important implications for human health [6,7]. Several studies have demonstrated detrimental health effects linked to PM exposure, including cardiovascular, pulmonary, and cognitive effects [6,7]. In general, the fine fraction of PM is primarily composed of elemental carbon or black carbon (BC), organic carbon, sulfate, nitrate, ammonium, and other inorganic constituents [8,9]. The principal sources of $\mathrm{BC}$ are related to combustion processes, such as diesel-emissions and biomass-burning. Some studies suggested that $\mathrm{BC}$ is a better indicator of harmful substances than those observed in $\mathrm{PM}_{2.5}$ or $\mathrm{PM}_{10}$ [10]. The impact of $\mathrm{BC}$ on the climate system is not well-known [11]. Some researchers have suggested that $\mathrm{BC}$ is one of the most important contributor to anthropogenic radiative forcing, after $\mathrm{CO}_{2}$ [12]. However, in terms of climate effects it is important to consider not only the emission of $\mathrm{BC}$ but also the role of co-emitted aerosols and gases [11]. The atmospheric processing after their emissions, due to transportation and physico-chemical transformation after emission, increases the complexity of evaluating BC climate effects. It is noteworthy that more than $60 \%$ of the total $\mathrm{BC}$ emissions in Latin America and the Caribbean (approximately $508 \mathrm{Gg} /$ year, responsible for up to 10 per cent of total global anthropogenic emissions of $\mathrm{BC}$ ) originate in Brazil and Mexico, the transport sector and residential combustion of solid fuels being the two main sources [13].

In megacities (those with over 10 million inhabitants), commuting is a highly complex process and requires multi-modal transport systems [14]. The MASP in Brazil is one of the greatest urban agglomerations in the world, with a population of more than 21 million inhabitants in $8000 \mathrm{~km}^{2}$ [15]. In the MASP, the vehicle fleet comprises more than 7 million vehicles [16], which has resulted in traffic congestion, impairing the quality of life, mainly during commute hours. A study conducted in 2007 showed the following distribution of commute modes in the MASP [17]: $28 \%$ by bus, $28 \%$ by passenger car; $10 \%$ by subway and train; $2 \%$ by motorcycle; and only $0.3 \%$ by taxi. It is noteworthy, however, that $31 \%$ of commutes were made by walking and $0.6 \%$ were made by bicycle, and that such commutes counter the risks of exposure to air pollution by contributing to the improvement of health [5].

The vehicle fleet in the MASP burns gasohol (25\% anhydrous ethanol $+75 \%$ gasoline), hydrous ethanol ( $5 \%$ water $+95 \%$ ethanol), or a diesel blend ( $7 \%$ biodiesel $+93 \%$ petroleum diesel). All buses and trucks are powered by diesel, compared to only $3 \%$ of light-duty vehicles (LDVs). In the MASP, the bus fleet increased from 44,062 buses in 2006 to 56,354 buses in 2016, when more than 12 million trips were made, daily [17]. It is noteworthy that although the population increased in this period, a commensurate increase in the size of the bus fleet assured that the ratio of inhabitants to buses remained almost constant, approximately 370 inhabitants per bus in the last six years (Figure 1). According to the official emission inventory of the transport sector, buses contributed only approximately $10 \%$ of the total vehicular fleet [16]. However, bus emissions are concentrated in the densely populated areas, such as bus terminals and corridors, affecting a large number of citizens during commute hours.

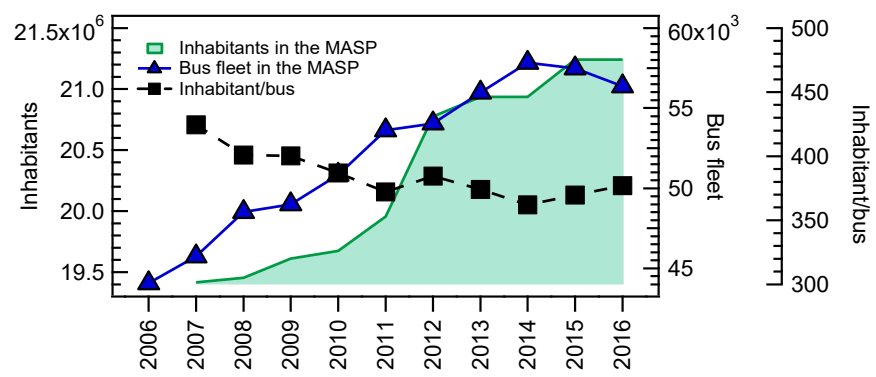

Figure 1. Annual evolution of the total population, bus fleet, and ratio of inhabitants to buses in the metropolitan area of Sao Paulo (MASP), from 2006 to 2016 [16]. 
The primary source of air pollutants in the MASP is its over seven million vehicles, which are responsible for over $90 \%$ of all emissions of $\mathrm{CO}$, nitrogen oxides $\left(\mathrm{NO}_{x}\right)$, and hydrocarbons $(\mathrm{HC})$. In 2016, LDVs accounted for $73 \%$ of CO emissions and $63 \%$ of HC emissions, whereas heavy-duty vehicles (HDVs) accounted for $48.8 \%$ of $\mathrm{NO}_{x}$ emissions [16]. Although fuel consumption increased between 2006 and 2016, the emissions inventory for $\mathrm{CO}, \mathrm{NO}_{x}$, aldehydes, and PM showed decreasing trends, due to the control of emission factors $[18,19]$. The reduction in pollutant emissions is due to regulatory programs instituted by the Brazilian government, primarily the Programa de Controle da Poluição do Ar por Veículos Automotores (PROCONVE, Program for the Control of Motor Vehicle Emissions). The PROCONVE has been updated continuously to include new quality standards and technological innovations, in order to reduce emissions and renovate the fleet, as well to expand the use and production of biofuels. In the PROCONVE phase 7, which corresponds to EURO V, new diesel motors (produced in 2013 and thereafter) are required to run on ultra-low-sulfur diesel fuel (sulfur-10 $\mathrm{mg} \mathrm{kg}^{-1}$ ), although older trucks and buses can still run on low-sulfur diesel fuel (sulfur-500 $\mathrm{mg} \mathrm{kg}^{-1}$ ) [20]. After 2017, all diesel fuel has been blended with $8 \%$ soy biodiesel.

Buses have been shown to constitute the main public transport mode used by commuters, in the urban and metropolitan regions of the MASP [17]. Although several campaigns to assess air quality and emissions have been carried out in the MASP, in recent years, the contribution of HDV emissions from buses is still unknown. In this study, we assessed for the first time the emission source profiles and spatial distribution of gaseous and particulate pollutants from buses burning on-road diesel ( $7 \%$ biodiesel $+93 \%$ petroleum diesel) in the MASP, based on experiments carried out in four different bus terminals.

\section{Experiments}

\subsection{Sampling Sites}

During 2016, intensive sampling campaigns were carried out at four bus terminals in Brazil, three in the MASP — Santo André (SA), Guarulhos (GRU), and Diadema (DIA)—and one in the city of Campinas (CAM), located $90 \mathrm{~km}$ west from the MASP. In 2016, the four terminals served a collective total of more than 300,000 passengers per day (Table 1). These terminals are part of the two corridors linking fourteen inter-city terminals and covering more than $80 \mathrm{~km}$. Most buses circulating were powered by engines meeting the EURO III standards, while electric buses circulated only at the SA and DIA terminals (Table 1). The locations of the bus terminals are shown in Figure 2.

At each terminal a small container was used to hold the monitors and instruments during the sampling period. As can be seen from Figure S1, the container was located in the middle of the boarding platform, next to the bus stop and the commuters. The inlet for gases and particles were placed at height of $2 \mathrm{~m}$ from the ground. The same container was used in each terminal, as well as in the inlets and monitor instruments.

Table 1. Characteristics of the four bus terminals under study in 2016.

\begin{tabular}{|c|c|c|c|}
\hline Terminal & Sampling Period & Passengers Per Day & $\begin{array}{l}\text { Number of Buses on } \\
\text { Weekdays/Weekends }\end{array}$ \\
\hline SA & May $12-30$ & 89,000 & $\begin{array}{c}\text { Electric: } 330 / 95 \\
\text { EURO II: } 605 / 400 \\
\text { EURO III: } 2315 / 1105 \\
\text { EURO V: } 332 / 114\end{array}$ \\
\hline GRU & June 3-16 & 39,000 & $\begin{array}{c}\text { EURO III: } 1380 / 727 \\
\text { EURO V: } 779 / 412\end{array}$ \\
\hline CAM & September 26-October 6 & 70,000 & $\begin{array}{c}\text { EURO II: } 22 / 12 \\
\text { EURO III: } 1798 / 982 \\
\text { EURO V: } 547 / 288\end{array}$ \\
\hline DIA & December 5-19 & 113,000 & $\begin{array}{c}\text { Electric: } 389 / 152 \\
\text { EURO II: } 104 / 49 \\
\text { EURO III: } 1789 / 802 \\
\text { EURO V: } 459 / 204\end{array}$ \\
\hline
\end{tabular}




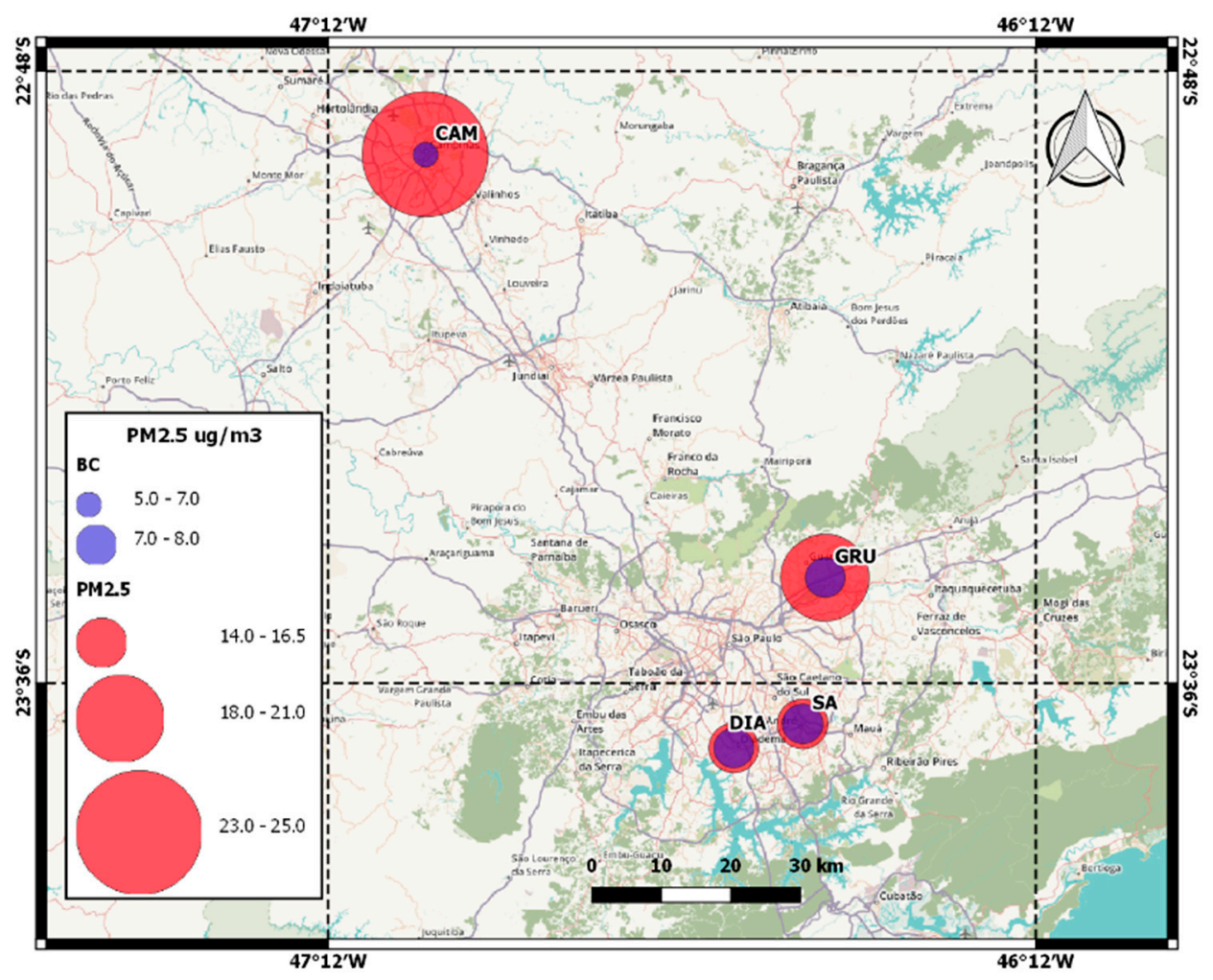

Figure 2. Map showing the locations of the bus terminals, the particulate matter $\left(\mathrm{PM}_{2.5}\right)$ concentrations being represented in red and the black carbon (BC) concentrations being represented in blue.

\section{2. $\mathrm{CO}_{2}$ and Conventional Gaseous Air Pollutants}

At all four bus terminals, $\mathrm{CO}_{2}$ and $\mathrm{CO}$ were measured with photoacoustic infrared spectroscopy (INNOVA 1412i; LumaSense, Santa Clara, CA), whereas $\mathrm{NO}_{x}$ was measured with chemiluminescence (42i analyzer; Thermo Fisher Scientific Inc., Franklin, MA, USA). The analyzers were inspected and tested in the laboratory, before and after the field campaigns, in order to provide high-quality measurements.

\subsection{VOC Sampling and Analytical Methods}

The HCs (C6-C11) were actively sampled by using adsorbent tubes, filled with Tenax-TA (Perkin-Elmer, Waltham, MA, USA). The samples were subsequently thermal desorbed and preconcentrated in a cryogenic trap, followed by chromatographic analysis in a thermal desorption-gas chromatography-flame ionization detector system. Before sampling, stainless-steel absorbent tubes $(90 \times 5 \mathrm{~mm})$ were conditioned for one hour, at $250^{\circ} \mathrm{C}$ with an $\mathrm{N}_{2}(6.0)$ flow of $100 \mathrm{~mL} / \mathrm{min}$. Sampling inside the SA bus terminal was performed in duplicates, throughout, approximately for $1 \mathrm{~h}$, at a flow of approximately $70 \mathrm{~mL} / \mathrm{min}$ and at room temperature $\left(20-25^{\circ} \mathrm{C}\right)$, on 23 May 2016. After sampling, the Tenax-TA-tubes were taken to the laboratory where automatic thermal desorption was performed (Turbo Matrix 650 ATD; Perkin-Elmer, Waltham, MA, USA). For this, the tubes were heated up to $250{ }^{\circ} \mathrm{C}$, for $10 \mathrm{~min}$, using $\mathrm{He}(50 \mathrm{~mL} / \mathrm{min})$ as a carrier gas. The desorbed compounds were collected in the trap at $-30{ }^{\circ} \mathrm{C}$, filled with solid carbon-adsorbents. Thereafter, the trap was heated at $325^{\circ} \mathrm{C}$, and the compounds were directed toward the analytical system. The HC identification was performed in a gas chromatograph, coupled with a flame ionization detector (GC-FID Clarus 500; Perkin-Elmer) [21].

Carbonyl sampling followed the Compendium Method TO-11 of the US EPA guidelines [22]. At the SA terminal, each sample was collected in a 2,4-dinitrophenylhydrazine-coated silica gel cartridge, for $2 \mathrm{~h}$, at an airflow rate of $0.9 \mathrm{~L} \mathrm{~min}^{-1}$, from 10 am to $8 \mathrm{pm}$, also on 23 May 2016. 
Analyses were performed by high-performance liquid chromatography, with UV-visible detection at $365 \mathrm{~nm}$ [23].

\subsection{PM Sampling and Analytical Methods}

At each bus terminal, PM samples were collected over an $18 \mathrm{~h}$ period (from 4 a.m. to 10 p.m.) with a system built in our laboratory. It consists of ten stacked filter unity (SFU), one pump, flowmeter, hour meter [24], and an automatic control system to change the SFU, according to the predefined sampling schedule. Each SFU consists of a polycarbonate filter holder, for two sequential filters constructed by the Norwegian Institute for Air Research (NILU, http:/ / products.nilu.no/ProductsDivision/FilterHolders. aspx), and using an inlet that provided a 50\% cut-off diameter of $10 \mu \mathrm{m}$. Each SFU sampler was loaded with a $47 \mathrm{~mm}$ diameter polycarbonate filter, with pore sizes of 8 and $0.4 \mu \mathrm{m}$, for collecting the fine $\left(\mathrm{PM}_{2.5}\right)$ and coarse $\left(\mathrm{PM}_{2.5-10}\right)$ fractions, respectively.

The measurements of the PM mass concentrations were performed by an electronic microbalance (MX5; Mettler-Toledo, Columbus, OH, USA). Filters were kept at $\sim 22{ }^{\circ} \mathrm{C}$ and $\sim 45 \%$ relative humidity, for $24 \mathrm{~h}$, prior to weighing. The measurements of the BC concentrations were performed by a digital smoke stain reflectometer (model 43D; Diffusions Systems Ltd., London, UK).

Elemental composition analysis was performed by energy dispersive X-ray fluorescence (EDX 700HS; Shimadzu Corporation, Analytical Instruments Division, Tokyo, Japan), as described previously [3,25]. Here, we identified and quantified Al, $\mathrm{Si}, \mathrm{P}, \mathrm{S}, \mathrm{Cl}, \mathrm{K}, \mathrm{Ca}, \mathrm{Ti}, \mathrm{V}, \mathrm{Cr}, \mathrm{Mn}, \mathrm{Fe}, \mathrm{Ni}, \mathrm{Zn}, \mathrm{Ga}$, $\mathrm{Br}, \mathrm{Zr}$, and $\mathrm{Pb}$.

\subsection{Enrichment Factors}

Airborne particles are major carriers of metals, some of which possess toxic properties, in part due to their biochemical activity, especially transition metals, such as $\mathrm{Fe}, \mathrm{V}, \mathrm{Ni}, \mathrm{Cr}, \mathrm{Cu}$, and $\mathrm{Zn}$. This relationship is standardized through the use of information on the concentrations of certain reference metals in the upper continental crust (UCC). The enrichment factor (EF) evaluates the contribution of anthropogenic emission of elements in atmospheric PM samples. The calculus considers the content of a potentially enriched element by its reference proxy, normalizing geochemical data to assess grain size, mineralogy, and the contributions of anomalous elements. Therefore, the EF can be estimated as follows:

$$
E F_{X}=(X / R E F)_{a i r} /(X / R E F)_{U C C}
$$

where $(X / R E F)$ is the concentration ratio of element $X$, in relation to a reference element. The contribution of anthropogenic sources to the concentrations of PM elements can be evaluated by the enrichment of resuspended soil dust, aluminum being chosen as a reference element due to its low anthropogenic emission and the chemical composition of the UCC [26]. EF values, ranging from the tens to the thousands, indicate anthropogenic contribution, and EF values close to single-digits indicate that crustal erosion is the primary source of the metal or element in question. EF values higher than 100 indicate a significant alteration in the geochemical cycles of the element, caused by anthropogenic activities [26].

\section{Results and Discussion}

\subsection{Regulated Gaseous Pollutants and $\mathrm{CO}_{2}$}

The official air quality monitoring network in MASP has thirty automatic stations where $\mathrm{PM}_{10}$, $\mathrm{PM}_{2.5}, \mathrm{CO}, \mathrm{NO}$, and $\mathrm{NO}_{2}$ are measured, hourly, in addition to $\mathrm{O}_{3}$ and $\mathrm{SO}_{2}$ [16]. In 2016, the annual mean concentrations were observed to be 29,15 , and $40 \mu \mathrm{g} \mathrm{m}{ }^{-3}$ for $\mathrm{PM}_{10}, \mathrm{PM}_{2.5}$, and $\mathrm{NO}_{2}$, respectively, and $0.8 \mathrm{ppm}$ annual mean concentrations ( $8 \mathrm{~h}$ averages) for CO [16]. Table 2 summarizes the atmospheric conditions in the MASP, during all campaigns. The atmospheric conditions, during the campaigns at the four bus terminals did not present significant differences among average temperatures. On the other hand, there were differences concerning rainfall, which was intense in May and June, 
during the days of the experiments. It must be highlighted that June (winter) is typically dry but it rained $131 \mathrm{~mm}$ for five days, from 3 to 7 June 2016. Due to this intense rain, MASP suffered serious problems with floods and traffic jams. Concerning the pollutants, MASP presented similar average concentrations during the campaigns, except for NO, which varied from 9.6 in September-October to 54.9 in June, the period which showed the highest pollutants concentrations. The concentrations of pollutants observed inside the terminals were always higher than that outside, except for $\mathrm{NO}_{2}$ for the experiments at the CAM and DIA terminals, corresponding to the periods with lower rainfall and cloud cover, favoring atmospheric photochemical processes.

Table 2. Concentrations values for pollutants, temperature, and rainfall outside the terminals during the campaigns $[16,27]$.

\begin{tabular}{cccccc}
\hline Parameter & unity & 12-30 May & 3-16 June & 26 Sep-6 Oct & 5-19 Dec \\
\hline $\mathrm{PM}_{10}$ & $\mu \mathrm{g} \mathrm{m}^{-3}$ & 23.8 & 32.6 & 22.9 & 23.9 \\
$\mathrm{PM}_{2.5}$ & $\mu \mathrm{g} \mathrm{m}^{-3}$ & 14.1 & 22.3 & 13.7 & 13.7 \\
$\mathrm{NO}$ & $\mathrm{ppb}$ & 21.4 & 54.9 & 9.6 & 22.1 \\
$\mathrm{NO}_{2}$ & $\mathrm{ppb}$ & 16.6 & 24.6 & 12.9 & 21.6 \\
$\mathrm{CO}$ & $\mathrm{ppm}$ & 0.6 & 1.0 & 0.6 & 0.5 \\
Temperature & ${ }^{\circ} \mathrm{C}$ & 17.3 & 12.7 & 16.7 & 22.0 \\
Rainfall & $\mathrm{mm}$ & 150 & 131 & 18 & 57 \\
\hline
\end{tabular}

Pollutant concentrations recorded at air quality monitoring stations located in the MASP and close to each bus terminal. The data was obtained from Santo André-Capuava, Santo André-Paço Municipal, São Bernardo do Campo-Centro, Diadema, São Caetano do Sul, São Paulo-Congonhas, São Paulo-Ponte dos Remédios, Guarulhos-Pimentas, Campinas-Centro, Campinas-Vila União, and Campinas-Taquaral stations.

At all bus terminals, the concentrations of gaseous pollutants showed two peaks per day, in the morning (6-8 a.m.) and in the afternoon (5-7 pm), as shown in Figure 3. The concentrations of these gases were often lower on the weekends, when fewer buses were running. It is noteworthy that the direct emission of $\mathrm{NO}$ by bus exhaust was the main source of the $\mathrm{NO}_{x}\left(\mathrm{NO}_{2}+\mathrm{NO}\right)$, inside all terminals. The hourly profiles of $\mathrm{CO}_{2}, \mathrm{CO}$, and $\mathrm{NO}$ concentrations showed good agreement with the number of buses circulating per hour. Buses with engines meeting the EURO III emissions standards were more abundant than those with engines meeting the EURO II or EURO V standards (Figures S2-S5). In addition, the mean $\mathrm{CO}$ and $\mathrm{NO}_{2}$ concentrations did not exceed the state air quality standards ( 9 ppmv $/ 8 \mathrm{~h}$ for $\mathrm{CO}$ and $128 \mathrm{ppbv} / \mathrm{h}$ for $\mathrm{NO}_{2}$ ), at any of the terminals under study.

All gases presented high concentrations on weekdays, being highest at the GRU terminal and lowest at the CAM terminal (Figure 3). The median concentrations of $\mathrm{CO}_{2}$ at the GRU, DIA, SA, and CAM terminals were 546, 526, 525, and 516 ppmv, respectively (Figure 3a). The median CO concentrations at the GRU and SA terminals were comparable (1.4, and $1.6 \mathrm{ppmv}$, respectively), with the highest concentrations being recorded at the DIA terminal (1.6 ppmv) and the lowest concentration (0.9 ppmv) at the CAM terminal (Figure 3b). At the GRU terminal, the median NO and $\mathrm{NO}_{2}$ concentrations were 126 and $34 \mathrm{ppbv}$, respectively (Figures $3 \mathrm{c}$ and $4 \mathrm{~d}$ ), compared with 103 and 31, at the DIA terminal; 86 and 22, at the SA terminal; and 48 and 26 ppbv, at the CAM terminal. These concentration differences might be explained by differences in the characteristics of the bus fleets and drive cycles. 

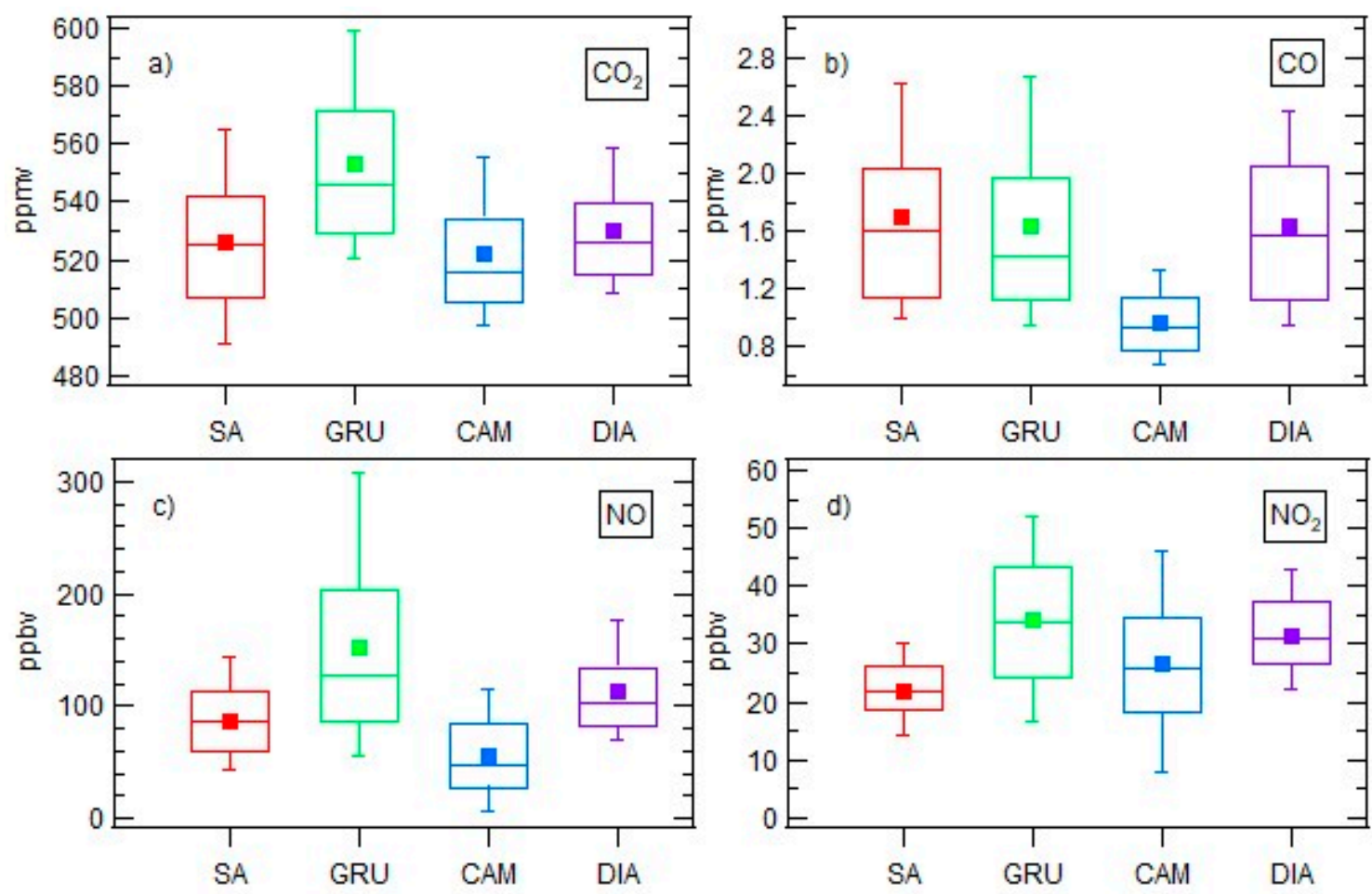

Figure 3. Box-whisker plots showing the hourly concentrations of (a) $\mathrm{CO}_{2} ;(\mathbf{b}) \mathrm{CO}$; (c) $\mathrm{NO}$; and (d) $\mathrm{NO}_{2}$ at the four terminals under study on a weekday from $4 \mathrm{am}$ to $10 \mathrm{pm}$. The rectangles represent the 25th and 75th percentiles, the lines and squares within the rectangles represent the medians and arithmetic means, respectively. The whiskers indicate the 10th and 90th percentiles.

\subsection{Emission Reductions and Future Outlook}

As was previously mentioned, the discrepancies in gaseous concentration inside the four terminals might be explained by differences in the characteristics of the bus fleets. For instance, all buses circulating through the GRU terminal were running on the biodiesel-petroleum diesel blend, whereas, some of the buses circulating through the SA and DIA terminals were electric (Table 1). Despite this, a comparison based on atmospheric concentrations inside the terminals did not provide adequate information to assess the contrasting bus fleet profiles. Thus, in order to explore whether ambient concentration inside terminals were impacted by the differences in bus fleet type, emission ratios (ER) were established by applying the linear regression fit method [28,29]. This method was used to calculate the slope of the scatterplot between two compounds, $\mathrm{CO}_{2}$ or $\mathrm{NO}$ versus $\mathrm{CO}$. Then, the slope obtained in this model was expressed as ER. The ER allowed a comparison of the real bus emissions at each terminal, removing the interferences of external parameters.

Figure 4 shows the $\mathrm{CO}_{2}$-to- $\mathrm{CO}$ and NO-to-CO ratios for the four bus terminals. Interestingly, SA and DIA terminals presented the lower ER, whereas CAM terminal presented the highest. The renovation of the bus fleet from Euro II to Euro $\mathrm{V}$ and the incorporation of electric buses seemed to have a noticeable impact on the emissions of $\mathrm{CO}_{2}$ and NO. The ER displayed a decrease by a factor of two to three in the $\mathrm{CO}_{2}$ emissions, when comparing the emission from older bus fleets (GRU and CAM, respectively). Even more achievable results were observed for the $\mathrm{NO} / \mathrm{CO}$ ratios, which showed a decrease by a factor of four to five (compared to GRU and CAM, respectively). NO emissions are commonly associated with diesel combustion engines, and their rate has been decreasing with the improvements of Euro technology [30]. While in Euro II, NOx emission factors were $0.9 \mathrm{~g} / \mathrm{km}$, in Euro $\mathrm{V}$ it decreased to $0.18 \mathrm{~g} / \mathrm{km}$. These changes could also explain the differences in the $\mathrm{NO} / \mathrm{CO}$ emission ratios, between DIA and SA. While both terminals showed a similar number of electric buses, the DIA terminal also included a newer fleet with a lower number of Euro II vehicles and a higher proportion of Euro V buses (pie-charts in Figure 4). 
Currently, a renovation plan of the MASP bus fleet is being developed, which aims to replace diesel by hybrid, electric, bus trails, or biofuel powered buses. This plan was stated in 2009 to meet the municipal agreement on climate change [31], by replacing 100\% of the MASP fleet, by 2018. However, only $2 \%$ of the fleet have been replaced by electric buses [14], until now. Our results suggest that the incorporation of buses with new technologies, such as electric buses, can have a considerable impact in the reduction of $\mathrm{NO}$ and $\mathrm{CO}_{2}$ emissions, by up to $40 \%$. Hence, these findings strengthened the fleet renovation policies, as well as the introduction of lower emission vehicles (i.e., electric buses) and, therefore, the improvement of air quality in the MASP.

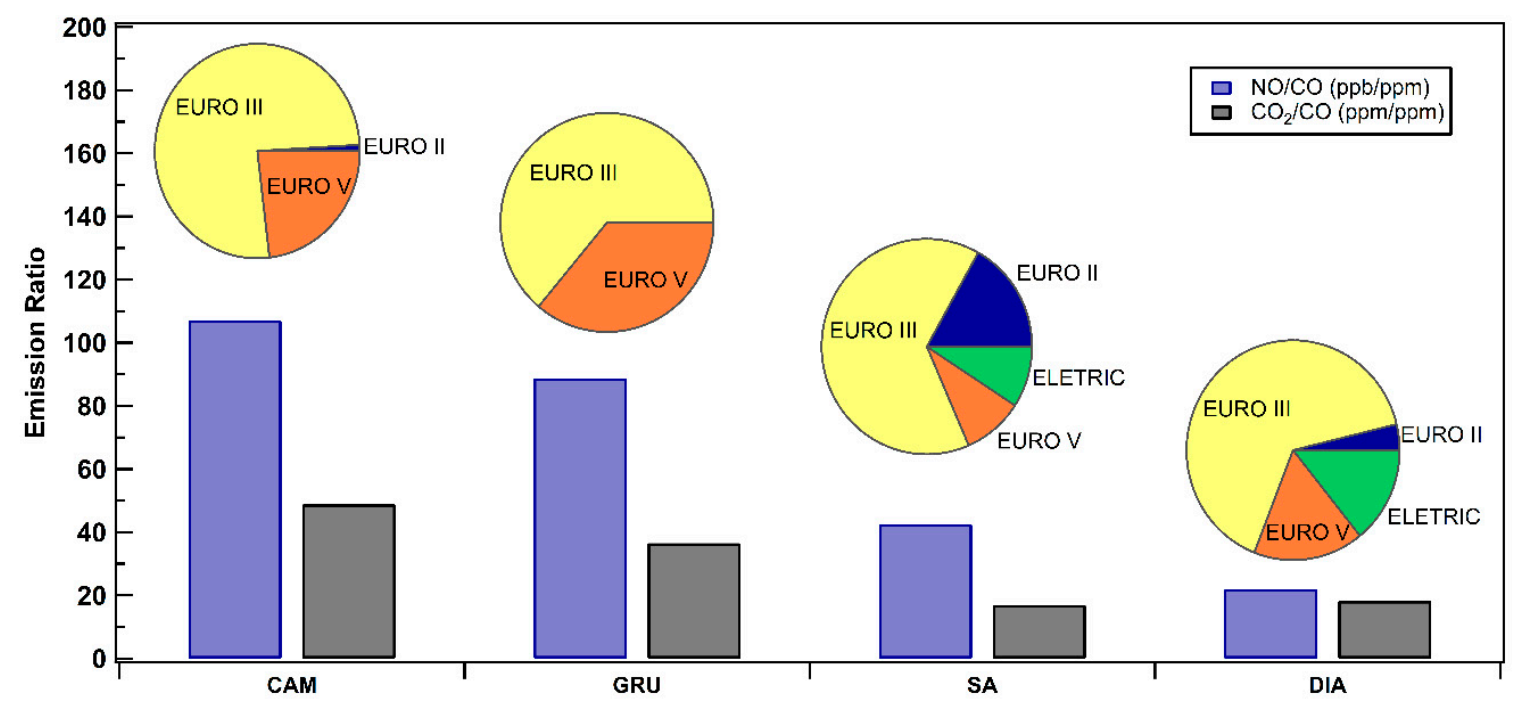

Figure 4. Emission ratios of $\mathrm{CO}_{2}$ to $\mathrm{CO}$ (ppm/ppm, bars) and $\mathrm{NO}$ to $\mathrm{CO}$ (ppb/ppm, bars) observed at the four bus terminals (Campinas (CAM), Guarulhos (GRU), Santo André (SA), and Diadema (DIA)). The pie-charts represent the relative composition of the fleet in each bus terminal.

\subsection{VOC Measurements}

The VOC emissions from gasoline and diesel exhausts have been widely evaluated in studies aimed to quantify their potential impact in the atmosphere, such as their $\mathrm{O}_{3}$-forming (OFPs) and secondary organic aerosol-forming potentials (SOAFP) [32-35]. However, most of those studies were conducted in northern mid-latitude urban areas with vehicle fleet compositions and diesel fuel usages different from those observed in Brazil. In addition, although there have been numerous in-bus studies aimed at assessing commuter exposure to VOC, few of these studies have integrated bus terminal measurements [36,37].

In order to evaluate the contributions of VOC from bus emissions under real-world conditions, a short campaign was performed at the SA terminal, located in an urban area of the MASP. As can be seen in Figure 5a, formaldehyde and acetaldehyde presented the highest daily mean concentrations (12.4 and $6.8 \mathrm{ppbv}$, respectively), followed by acrolein+acetone (2.9 ppbv). Other noteworthy VOC levels were those of C11 aliphatic HCs (2.11 ppbv), C9 aromatics (1.94 ppbv), C8 aromatics (1.49 ppbv), toluene (1.14 ppbv), C10 aromatics ( $0.51 \mathrm{ppbv})$, and benzene $(0.39 \mathrm{ppbv})$. The hourly variability was significant for toluene, which presented higher concentrations in the morning (Figure 5a). 

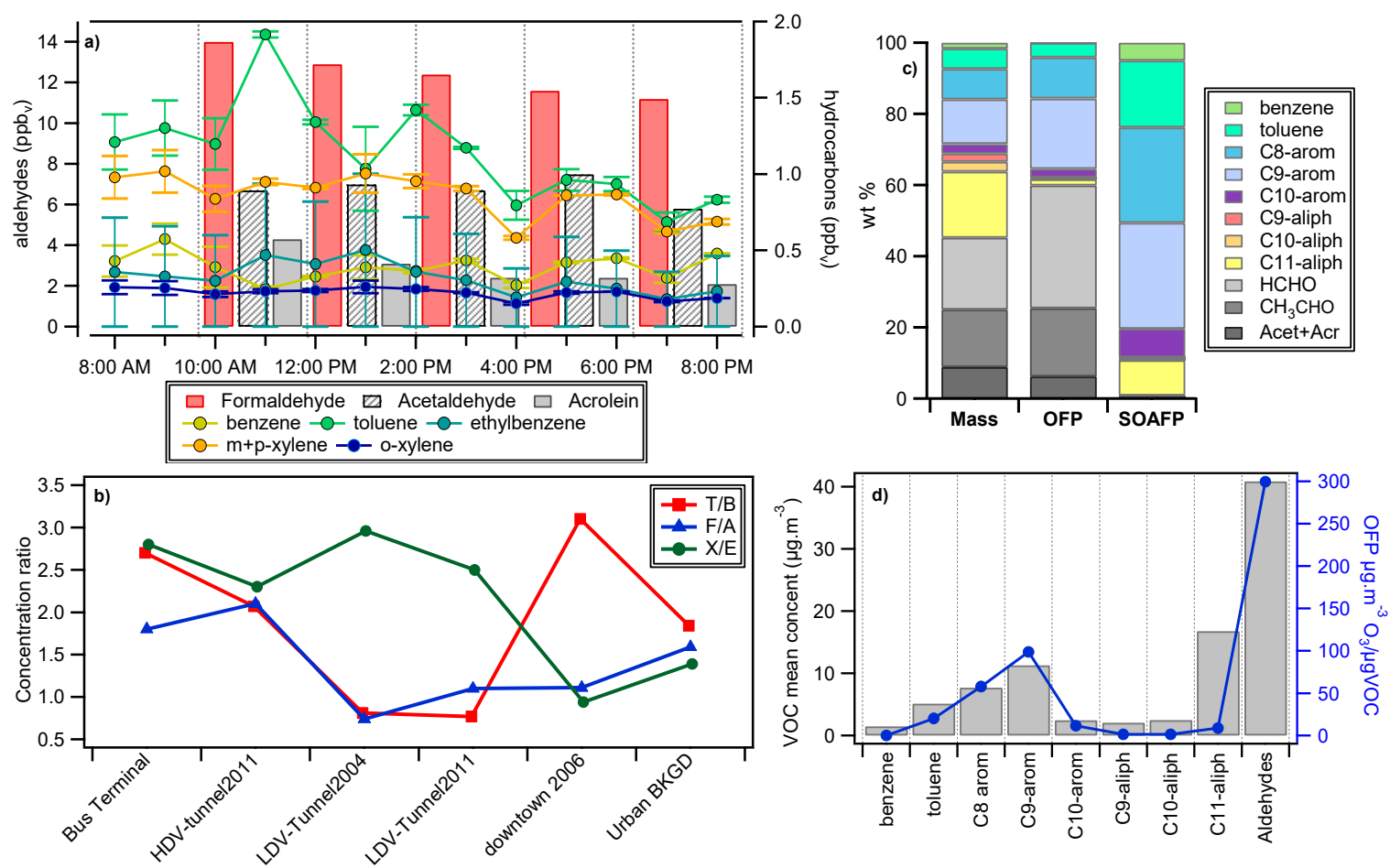

Figure 5. (a) Mean concentrations and the standard deviation of aldehydes and selected non-methane hydrocarbons (HCs) at the SA bus terminal; (b) VOC relative mass contribution, relative O3-forming $(\mathrm{OFP})$ calculated from the maximum incremental reactivity scale, and relative secondary organic aerosol-forming potentials (SOAFP); (c) toluene/benzene (T/B), formaldehyde/acetaldehyde (F/A), and $\mathrm{m}+\mathrm{p}$-xylene to ethylbenzene $(\mathrm{X} / \mathrm{E})$ ratios, with urban background (BKGD) values; and (d) mean concentrations (gray bars, left axis) and OFPs (blue line, right axis) of VOC.

The mean aldehyde concentrations measured at the SA bus terminal were higher than those reported in a study performed in the city of Londrina, Brazil $[38,39]$. In our study, the mean formaldehyde and acetaldehyde concentrations were $12.4 \pm 0.3$ and $6.8 \pm 0.2 \mathrm{ppbv}$, respectively, 1.6 and 5.4 times higher than those observed in Londrina in 2002, when all buses ran on petroleum diesel (without the addition of biodiesel) [38]. However, comparing our data with another Londrina study, formaldehyde and acetaldehyde concentrations were, respectively, 4.9 and 1.1 times higher than those measured at the Londrina bus terminal in 2008. At this time, all buses ran on fuel composed of $3 \%$ biodiesel and $97 \%$ petroleum diesel [39]. The disparity in acetaldehyde levels could be related to the changes in bus engine technologies and to the reformulation of diesel fuel in the last ten years, fuel incorporating 7\% biodiesel has been in use since 2014. Studies carried out in the city of Salvador, Brazil, also demonstrated that acetaldehyde emissions changed when buses started to run on the biodiesel-petroleum diesel blend [40]. At the Salvador bus terminal, formaldehyde and acetaldehyde concentrations were 1.5 and 6.9 times higher in 2010, when all buses ran on fuel composed of biodiesel and petroleum diesel [40], than in 1997 when they ran on petroleum diesel alone [41]. Despite that reduction, formaldehyde and acetaldehyde concentrations were 6.4 and 12 times higher, respectively, than those observed in our study. The dissimilarities among aldehyde concentrations in bus terminals could be related to the ages of the fleets, which were renovated more frequently in the MASP, than in other Brazilian cities [20]. It is worth mentioning that differences in engine temperatures and driving speed could affect the vehicular emissions and contribute with the disparity in our comparison. However, the patterns observed for other pollutants are in an opposite trend to those reported for aldehydes.

VOC concentration ratios were computed to analyze the contribution of emissions from buses running on the biodiesel-petroleum diesel blend and then compared with those reported in previous 
studies, as depicted in Figure $5 b$ [21,23,42-44]. The mean xylene/ethylbenzene (X/E), toluene/benzene $(\mathrm{T} / \mathrm{B})$, and formaldehyde/acetaldehyde (F/A) ratios observed during our campaigns were $2.8 \pm 0.5$, $2.7 \pm 0.7$, and $1.8 \pm 0.2$, respectively, slightly higher than those observed in an HDV tunnel campaign [43], except for the F/A ratio, which was lower [44]. The differences among the T/B ratios could be related to the changes in the formulation of the benzene-diesel content, which induced a decrease in benzene emissions in the last years. The T/B ratios observed in the present study were 2.1, which was similar to that reported in a study on bus emissions in the city of Hangzhou, China [37], as well as those reported in a study performed in London, England, where the ratio ranged from 2.2-2.6 [32]. The T/B ratio can indicate the age of the plume-related to the reactivity and lifetime of both compounds, ratios of 2.0-2.4 being associated with fresh emissions [45]. Therefore, as expected, the ratio observed at the SA bus terminal suggested that the VOC were from fresh emissions. The X/E ratio could be useful to estimate the intensity of atmospheric photochemical reactivity [46]. Xylenes and ethylbenzene were commonly emitted together. However, due to the difference in their atmospheric lifetimes (5.9 $\mathrm{h}$ for xylenes and 1.7 days for ethylbenzene) [47], the ratio decreased rapidly as the distance from the source increased [48]. The mean X/E ratio obtained in the present study $(2.8 \pm 0.5)$ was on the same order as those obtained in campaigns carried out in road tunnels in the MASP; that is, in the absence of photochemical processes (Figure $5 b$ ). In contrast, our X/E ratios were higher than the urban background levels, suggesting that both compounds were directly emitted by buses.

The F/A ratio observed at the SA bus terminal was higher than those observed at other bus terminals. In Londrina, the F/A ratio decreased from 6.3 in 2002, when buses were running on diesel [38], to 0.4 in 2008, when buses were running on fuel composed of $3 \%$ biodiesel and 97\% petroleum diesel [39]. In Salvador, the F/A ratio decreased from 4.4 in 1997 [41] to 0.97 in 2010, when buses were running on fuel composed of $5 \%$ biodiesel and $95 \%$ petroleum diesel, respectively [40]. In Brazil, the increase of acetaldehyde concentrations has been considered a drawback of ethanol use related to LDV combustion processes, as evidenced by the fact that lower F/A ratios have been reported in proximity to LDV emissions $[19,23,44,49]$. However, lower F/A ratios associated with biodiesel use have also been reported in the Brazilian urban areas [39,40,50-52].

The ability of VOC to produce SOA is related to the reactivity and volatility of the species emitted, as well as to the fraction of organic carbon available for this process $[53,54]$. Each VOC has a specific, distinct reaction mechanism. However, in general, the reactions and yields of $\mathrm{SOA}$ and $\mathrm{O}_{3}$ become more complex with an increase in the number of carbons of each VOC species [32,55]. The SOAFP index expresses the modelled mass of aerosol formed per mass, for a particular VOC reaction; for example, the SOAFP index for toluene is 100. The SOAFP values are limited to many HCs and have been used to estimate values for all other species, based on chemical similarities [56,57]. We evaluated the SOAFP indices for individual VOC species and for their aggregation into VOC families, finding that C 8 and C 9 aromatics constituted the most significant fraction for SOA formation from diesel emissions, followed by toluene and C11 aliphatic HCs (Figure 5c). This relative SOAFP profile was similar to those observed in London, where heavy aliphatic HC (C11- to C13-) and C3-substituted mono-aromatic compounds controlled the SOA yield [32]. A previous study showed that the SOAFP was 6.7 times higher for diesel than for gasoline, SOAs being formed mainly from aromatics in gasoline and from aliphatic HCs (47\%) in diesel emissions [33]. The differences in our study could be related to the limitation in the species analyzed, since we did not quantify HCs higher than C12. Further studies should be accomplished in order to quantify the semi-VOC/IVOC fraction from biodiesel emissions for a better estimation of the SOA formation processes in the MASP.

Despite the preponderance of aldehydes in the relative mass contribution of the total VOC mass measured at the SA bus terminal, they did not have important contributions in the SOAFP (Figure 5c). However, due to their reactivity, aldehydes played a significant role in oxidation reactions and in the $\mathrm{O}_{3}$ formation, in urban atmospheres $[47,56,58]$. To assess the effects that the observed VOC concentrations had on the local $\mathrm{O}_{3}$ production, we calculated the OFP by using the maximum incremental reactivity scale, estimated by photochemical simulations [58]. The OFP values calculated for the VOC observed 
at the SA bus terminal showed that oxygenated compounds made a clearly predominant $(60 \%)$ contribution (Figure 5c), with an estimated OFP of $300 \mu \mathrm{g} \mathrm{O} 3 / \mathrm{m}^{3}$ in the MASP atmosphere (Figure $5 \mathrm{~d}$ ). At the Londrina bus terminal, the OFP for buses running on $3 \%$ biodiesel $+97 \%$ petroleum diesel was $101.6 \mu \mathrm{g} \mathrm{O}_{3} / \mathrm{m}^{3}$ [39], compared to only $81.3 \mu \mathrm{g} \mathrm{O} 3 / \mathrm{m}^{3}$, for buses running on petroleum diesel alone [38]. Therefore, the higher OFP values observed at the SA bus terminal could be attributable to the higher biodiesel content in the fuel, burned by the MASP bus fleet.

\section{4. $P M_{10}$ and $P M_{2.5}$ Concentrations}

The concentrations of $\mathrm{PM}_{2.5}$ and $\mathrm{PM}_{10}$ on weekdays showed a wide range, at all terminals (Figures 6a and 7b). The weekday mean $\mathrm{PM}_{10}$ concentrations were as follows: $53.9 \pm 19.4 \mu \mathrm{g} \mathrm{m}^{-3}$ at GRU; $46.7 \pm 14.8 \mu \mathrm{g} \mathrm{m}^{-3}$ at CAM; $39.2 \pm 11.8 \mu \mathrm{g} \mathrm{m}^{-3}$ at DIA; $34.6 \pm 8.9 \mu \mathrm{g} \mathrm{m}^{-3}$ at SA. The weekday average $\mathrm{PM}_{2.5}$ concentrations were as follows: $19.9 \pm 8.3 \mu \mathrm{g} \mathrm{m}^{-3}$ at GRU; $23.5 \pm 5.6 \mu \mathrm{g} \mathrm{m}^{-3}$ at CAM; $16.5 \pm 7.8 \mu \mathrm{g} \mathrm{m}^{-3}$ at DIA; and $15.0 \pm 5.7 \mu \mathrm{g} \mathrm{m}^{-3}$ at SA. The statistical analyses is summarized in Table S1. On average, $\mathrm{PM}_{2.5}$ accounted for $40 \%$ of the $\mathrm{PM}_{10}$ mass, reaching more than $50 \%$ at the CAM terminal (Figure 6c). It is known that HDVs constitute the main source of BC emissions in the MASP [14]. BC accounted for a significant fraction of $\mathrm{PM}_{2.5}$, mainly at the SA and DIA terminals (50\% and $40 \%$, respectively) where, interestingly, the lowest $\mathrm{PM}_{2.5}$ concentrations were reported (Figure $5 \mathrm{~d}$ ). The higher $\mathrm{BC}$ fraction of $\mathrm{PM}_{2.5}$ also suggests a lower organic contribution at these terminals, where electric buses has been introduced to the fleet. Replacing older buses with newer ones that incorporate improved technologies, according to the later phases of the PROCONVE for Diesel-Powered Vehicle, would reduce the emission of particulate matter and $\mathrm{BC}$.

For $\mathrm{PM}_{10}$, the World Health Organization (WHO) recommends a daily average limit of $50 \mu \mathrm{g} \mathrm{m}^{-3}$ [59], although the legislation in Brazil, which is less restrictive, sets $150 \mu \mathrm{g} \mathrm{m}^{-3}$ as the national standard and $120 \mu \mathrm{g} \mathrm{m}^{-3}$ as the standard for the state of São Paulo [16,60]. The concentrations obtained here were compared with the air quality standards to evaluate the health impact. $\mathrm{PM}_{10}$ and $\mathrm{PM}_{2.5}$ concentrations surpassed the WHO-recommended limit, at least once, during the study period, at all bus terminals evaluated (Figure S7). However, no exceedances were observed in relation to the national or local standards.

Figure 2 shows the geolocations of the bus terminal under study, together with the mean concentration of $\mathrm{PM}_{2.5}$, at each location. Higher $\mathrm{PM}_{2.5}$ concentrations were observed at the GRU and CAM terminals, where the maximum daily values exceeded the WHO-recommended daily limit of $25 \mu \mathrm{g} \mathrm{m}^{-3}$ [59]. The exceedances of the WHO-recommended limits notwithstanding, the PM levels found for the bus terminals here were lower than those obtained in other Brazilian bus terminals. For instance, at a bus terminal in the city of Salvador, the mean values for $\mathrm{PM}_{10}$ and $\mathrm{PM}_{2.5}$ were $309 \pm 56 \mu \mathrm{g} \mathrm{m}^{-3}$ and $201 \pm 56 \mu \mathrm{g} \mathrm{m}^{-3}$, respectively [61]. In another study carried out in the city of Londrina, the $\mathrm{PM}_{10}$ and $\mathrm{PM}_{2.5}$ mass concentrations observed at a bus terminal, were $49.8 \pm 10 \mu \mathrm{g}$ $\mathrm{m}^{-3}$ and $38.0 \pm 8.6 \mu \mathrm{g} \mathrm{m}^{-3}$, respectively [62]. In addition, the $\mathrm{PM}_{2.5}$ concentrations observed in our study were two and nine times lower, respectively, than those reported for two road tunnels in the MASP —one traveled primarily by LDVs and one traveled by LDVs and HDVs [25]. The mean $\mathrm{PM}_{10}$ concentrations observed here were slightly higher than the average $44 \mu \mathrm{g} \mathrm{m}^{-3}$ (range, 12-113 $\mu \mathrm{g} \mathrm{m}^{-3}$ ) reported in a recent study carried out in the MASP [63]. Nevertheless, the mean $\mathrm{PM}_{2.5}$ concentration reported in that study—average $30 \mathrm{\mu g} \mathrm{m}^{-3}$ (range, 8-78 $\mathrm{\mu g} \mathrm{m}^{-3}$ )—was higher than that measured at any other evaluated bus terminal. 


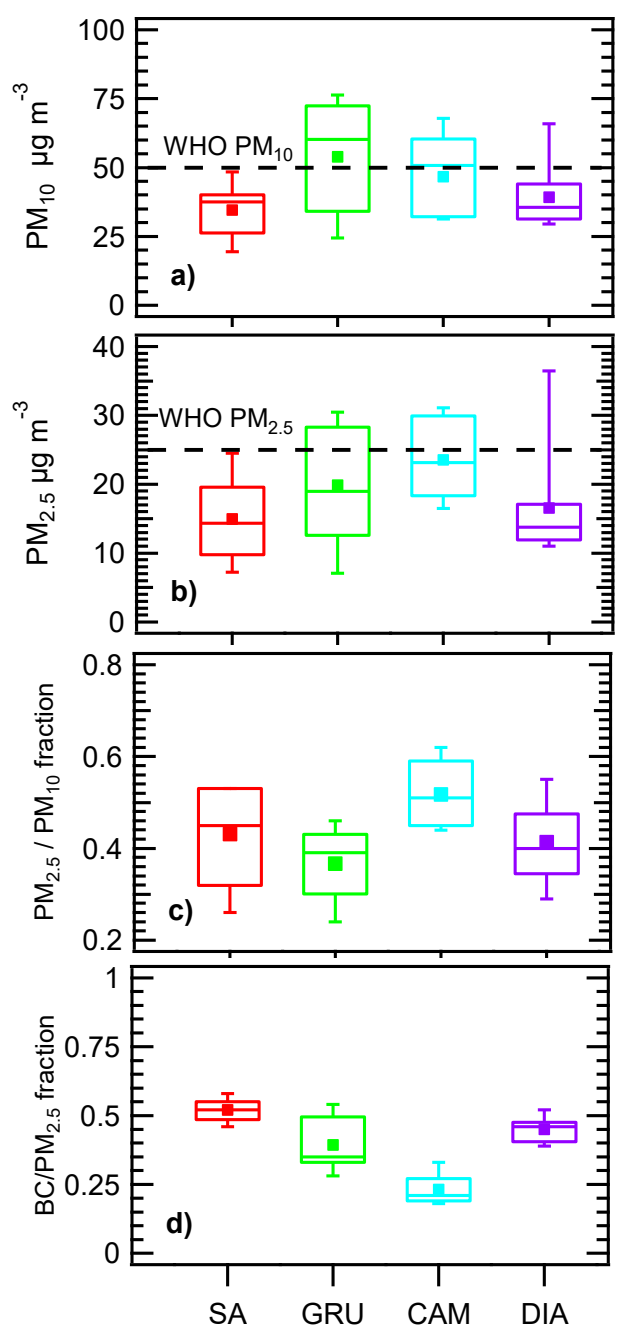

Figure 6. Box-whisker plots showing the (a) $\mathrm{PM}_{10}$ concentrations, (b) $\mathrm{PM}_{2.5}$ concentrations, (c) $\mathrm{PM}_{2.5} / \mathrm{PM}_{10}$ fraction, and (d) the $\mathrm{BC} / \mathrm{PM}_{2.5}$ fraction at the four bus terminals under study. The rectangles represent the 25th and 75th percentiles; the lines and squares within the rectangles represent the medians and arithmetic means, respectively. The whiskers indicate the 10th and 90th percentiles.

The PM measurements performed in our study provided an interesting dataset for the evaluation of HDV emissions, under real-world conditions. Given that the bus fleet is responsible for most of the emissions of $\mathrm{PM}_{2.5}$ at the terminals, the emission ratios between $\mathrm{PM}_{2.5}$ and $\mathrm{PM}_{10}$ were evaluated by applying the linear regression fit method. In our study, the ratio obtained was 0.39 (Figure 7), compared to 0.81 , which was obtained in a previous HDV-tunnel campaign carried out in MASP [25,64]. The $\mathrm{PM}_{2.5} / \mathrm{PM}_{10}$ emission ratios observed in the present study were lower than those previously found for two other bus terminals in Brazil, 0.80 at a terminal in Londrina [62]; and 0.61 at one in Salvador [61]. We also observed a shift when only weekday data were analyzed, the ratio increased from 0.39 to $0.53 \mu \mathrm{g}$ $\mathrm{m}^{-3} / \mu \mathrm{g} \mathrm{m}^{-3}$. That difference could be attributable to the $30-60 \%$ decrease in the size of the circulating fleet on weekends (Table 1). Likely the values in the MASP were lower, because the buses circulating in the MASP were newer (6-12 years old) than those circulating elsewhere (18-25 years old) [20]. In addition, electric buses composed $14 \%$ of the bus fleet circulating through the MASP terminals, which reduced combustion-related emissions. Furthermore, the campaigns conducted elsewhere in Brazil were carried out before 2012, when PROCONVE phase 7, was implemented. Our results above suggest that the newer bus fleet in the MASP emitted fewer particles than did the older fleets evaluated in previous studies. 


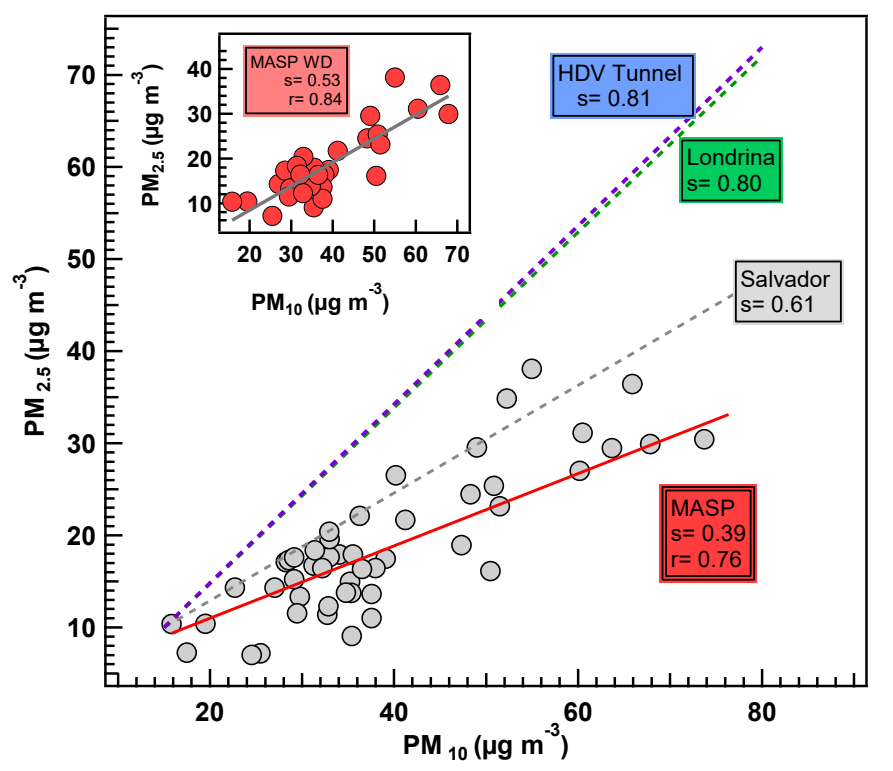

Figure 7. Scatter plot of $\mathrm{PM}_{2.5}$ versus $\mathrm{PM}_{10}$ data obtained at all bus terminals (grey filled circles). The red line represents the $\mathrm{PM}_{2.5} / \mathrm{PM}_{10}$ emission ratio calculated from the linear regression fit method for this study ( $\mathrm{s}=$ slope and $\mathrm{r}=$ Pearson's correlation coefficient). Green, grey, and blue lines illustrate slopes obtained in previous studies developed in Londrina [62], Salvador [61], and in an heavy-duty vehicles (HDV)-traveled tunnel in the MASP [25,64], respectively. The scatter plot embedded in the upper left corner (red filled circles) displays the result for weekday (WD) samples at the bus terminals under study.

\subsection{BC Concentrations}

In the MASP, emissions of BC are mainly from HDVs [14,65]. In the present study, the mean $\mathrm{BC}$ concentrations at the SA, GRU, CAM, and DIA bus terminals were $7.7 \pm 2.5,7.2 \pm 2.0,5.3 \pm 1.0$, and $7.4 \pm 3.2 \mu \mathrm{g} \mathrm{m}^{-3}$, respectively. Figure 2 shows the geolocations of the four terminals, together with the mean concentration of $\mathrm{BC}$ at each. Table S1 summarizes the statistical analyses for the BC concentrations at all terminals under study in 2016.

The $\mathrm{BC} / \mathrm{PM}_{2.5}$ ratios observed in the present study are similar to those recorded in other places, worldwide, where policies to regulate diesel emissions have been delayed [66]. The mean weekday contribution of $\mathrm{BC}$ to $\mathrm{PM}_{2.5}$ was $0.45,0.52,0.39$, and 0.23 at the DIA, SA, GRU, and CAM bus terminals, respectively (Figure 6d). In 2004, before the addition of biodiesel to diesel became mandatory, this contribution was approximately 0.79 [65]. In contrast in 2011 when the HDV fleet began to run on the blend of 5\% biodiesel, the contribution decreased to 0.61 [25]. Our results indicate that elemental carbon, (BC concentration), has decreased its contribution to the total mass of $\mathrm{PM}_{2.5}$. These findings are in agreement with those of other studies showing that elemental carbon emissions decreased in response to an increase in the proportion of the biodiesel content $[67,68]$. However, the contribution that organic carbon makes to the total $\mathrm{PM}_{2.5}$ mass might have increased. As shown in Figure $\mathrm{S} 8$ and Table S2, the sum of BC and elemental concentrations accounted for less than $60 \%$ of the total mass concentration of $\mathrm{PM}_{2.5}$. The remainder fraction likely accounted for organic carbon and ion species. The concentrations of atmospheric ions, such as sulfate, nitrate, and ammonium had not increased over time, in the MASP [63]. In fact, sulfate concentrations had decreased in the last ten years [60], which could indicate a high contribution to the organic fraction.

\subsection{Source Profile Based on the Mass Balance}

The mass balance was calculated for each terminal, considering the elements of crustal or exhaust emission and the $\mathrm{BC}$ contribution to the $\mathrm{PM}_{2.5}$ (Figure S8a) and $\mathrm{PM}_{2.5-10}$ fraction (Figure S8b). Mass balances were calculated only for the SA, GRU, and CAM terminals, where the elemental analysis 
was performed. Table $\mathrm{S} 3$ shows the composition of the $\mathrm{PM}_{2.5-10}$ samples collected from each terminal under study. At the SA, GRU, and CAM terminals, respectively, $40.0 \%, 33.5 \%$, and $22.7 \%$ of the $\mathrm{PM}_{2.5-10}$ mass was explained, of which $\mathrm{BC}$ represents $7.0 \%, 4.4 \%$, and $2.0 \%$, respectively. $\mathrm{Si}$, as silicon dioxide was the second most abundant species at all of the terminals, accounting for $6.6 \%, 8.3 \%$, and $8.4 \%$ of the $\mathrm{PM}_{2.5-10}$ mass at the SA, GRU, and CAM, respectively.

Regarding the $\mathrm{PM}_{2.5}, \mathrm{BC}$ accounted for $44.5 \%, 37.0 \%$, and $20.7 \%$ of the mass concentration at $\mathrm{SA}$, GRU, and CAM respectively. $\mathrm{S}$ was the second most important species, accounting for $7.9 \%, 4.8 \%$, and $5.8 \%$ of the $\mathrm{PM}_{2.5}$ mass concentration at the SA, GRU, and CAM, respectively, underscoring the fact that organic carbon was not measured in the samples.

The comparison between our results and the in-tunnel measurements conducted in a previous study in the MASP, in terms of the elemental mass fractions of the $\mathrm{PM}_{2.5-10}$ and $\mathrm{PM}_{2.5}$, is shown in Figure S8. The elemental mass distributions at the terminals were quite similar to those found in the tunnels, highlighting the contributions that the low-atomic-weight elements $(\mathrm{Al}, \mathrm{Si}, \mathrm{Cl}$, and $\mathrm{S})$ and the Fe made to the $\mathrm{PM}_{2.5-10}$ fraction. However, the highest trace element contribution to the $\mathrm{PM}_{2.5}$ mass concentration came from $\mathrm{S}$.

The concentrations of elements to the $\mathrm{PM}_{2.5}$ fractions inside the bus terminals are shown in Table S4. The concentrations of $\mathrm{S}$, the most abundant element in the $\mathrm{PM}_{2.5}$ fraction, were 1110 $\pm 790,931 \pm 547$, and $1297 \pm 330 \mathrm{ng} \mathrm{m}^{-3}$ at the SA, GRU, and CAM terminals, respectively. These values were significantly lower than that observed inside a road tunnel in the MASP, in 2011 $\left(3657 \pm 781 \mathrm{ng} \mathrm{m}^{-3}\right)$. In that same year, all diesel fuel sold in Brazil contained 5\% biodiesel, with a sulfur content of $50-1800 \mathrm{mg} \mathrm{kg}^{-1}$, whereas that sold in 2016 contained $7 \%$ biodiesel, with a sulfur content of $10-500 \mathrm{mg} \mathrm{kg}^{-1}$. At the SA and GRU terminals, BC showed good correlations with $\mathrm{S}$ $(\mathrm{r}=0.93$ and 0.86 , respectively).

\subsection{Enrichment Factors (EFs)}

To calculate EFs for the SA, CAM, and GRU bus terminals, we used aluminum as a surrogate for the UCC. In addition, as stated in Section 3.6, the DIA bus terminal was not included due to shortcomings of the elemental analysis. Although several studies have employed the Taylor-McLennan dataset [69] as the UCC for EF calculation, we used the Hetem-Andrade dataset [66] as a more appropriate profile for resuspended road dust at bus terminals under study.

Figure 8 depicts the EFs, calculated as box plots, for all of elements, contributing to the fine and coarse fractions $\left(\mathrm{PM}_{2.5}\right.$ and $\mathrm{PM}_{2.5-10}$, respectively). It is noteworthy that $\mathrm{S}$ was the most enriched element for the fine mode at all the bus terminals, corroborating the mass balance analysis (Figure S8). For the SA, CAM, and GRU terminals, the EF values for $S$ were higher than 100, which indicates a pronounced alteration by local emissions $[25,26]$. For the SA and GRU terminals, the fine PM profiles were similar, with S-, Cl-, and Cr-enriched samples, those elements, therefore, were apportioned to vehicular sources. Although the coarse fraction presented a similar pattern at the SA and GRU terminals, there were several outliers at the $\mathrm{SA}$ terminal, including $\mathrm{V}, \mathrm{Mn}, \mathrm{Fe}, \mathrm{Ni}, \mathrm{Cu}, \mathrm{Zn}$, and $\mathrm{Pb}$. At the CAM terminal, the EF values presented a different behavior, with less-enriched samples, a discrepancy that could be attributable to the better ventilation at the CAM terminal, as previously mentioned. For the SA and GRU terminals, the overall EF analysis apportioned $\mathrm{Mg}, \mathrm{Si}, \mathrm{Ca}, \mathrm{Ti}, \mathrm{Mn}$, and $\mathrm{Fe}$ as crustal sources (EF values near 1 ) for the fine fraction, whereas most of the same elements presented mixed EF values (between 1 and 10) for the coarse fraction, indicating contributions from vehicular and crustal sources. Similar patterns were observed in a road tunnel in the MASP, $\mathrm{Cu}$ and $\mathrm{Zn}$ also being apportioned to vehicle emissions, due to tire and brake wear [25]. 

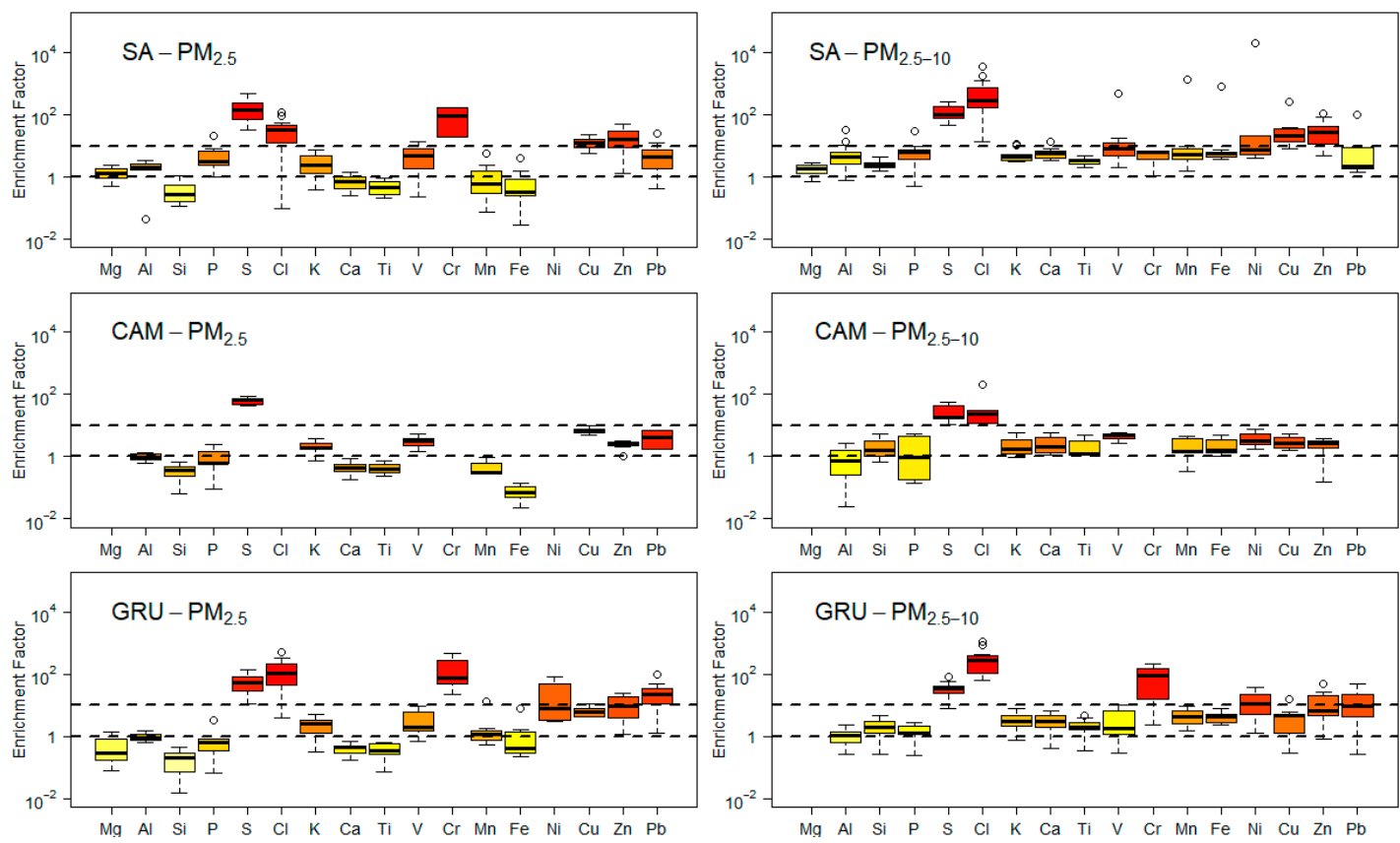

Figure 8. Box-whisker plots showing the EFs, for the $\mathrm{PM}_{2.5}$ and $\mathrm{PM}_{2.5-10}$ fractions (left and right sides, respectively), calculated for samples obtained at the SA, CAM, and GRU bus terminals. Dashed lines represent the 1-10 range of ratios. Upper continental crust (UCC) samples considered the MASP crustal samples [66].

\section{Conclusions}

Pollutants such as $\mathrm{NO}_{x}, \mathrm{CO}, \mathrm{VOC}, \mathrm{PM}_{10}$, and $\mathrm{PM}_{2.5}$, as well as their constituents, were identified and quantified in four bus terminals, during intensive campaigns carried out in the MASP, and in the city of Campinas. The resulting detailed dataset provided the first glimpse into the profile of pollutants emitted by buses in the region.

Although measured at only one site (the SA bus terminal), aldehydes were found to be the dominant fraction of VOC, accounting for $60 \%$ of the OFP. Regarding the SOAFP, the data showed that $\mathrm{C} 8$ and $\mathrm{C} 9$ aromatics constituted the most significant fraction of emissions from diesel-powered city buses. Nevertheless, the results shown here are limited to certain VOC species found in emissions from vehicles running on biodiesel-petroleum diesel fuel blends. Further studies are needed in order to quantify the semi-VOC/intermediate-VOC fraction for a better estimation of the impact on SOA formation processes in the MASP and elsewhere in Brazil.

Our findings suggest that the current bus fleet in the MASP, which comprises newer vehicles, emits fewer particles than those evaluated in previous studies.

Previous studies have listed the hazards associated with high concentrations of $B C$ in the atmosphere. The WHO reported that there is a clear association between concentrations of BC and mortality, due to cardiovascular and cardiopulmonary diseases. In addition, several studies have demonstrated that BC increases global warming. Here, BC accounted for $20-43 \%$ of the PM fraction, which is lower than the proportions reported in previous studies conducted in the MASP. However, our bus terminal measurements also revealed that the population is exposed to a number of harmful pollutants. For instance, the trace elements identified in our samples showed that vehicle emissions made significant contributions to the fine and coarse fractions of hazardous metals, such as $\mathrm{Cr}, \mathrm{Zn}, \mathrm{V}$, and $\mathrm{Pb}$. Further analyses are needed to quantify the risk associated with public exposure to vehicle emissions, during commute hours.

The results of our study suggest that the incorporation of buses with new technologies, such as electric buses, can have a considerable impact-by up to $40 \%$ - on the process of $\mathrm{NO}$ and $\mathrm{CO}_{2}$ 
emissions reduction. Additionally, the decrease of these emissions might also have benefits on air quality and, therefore, in the bus emissions exposure to commuters.

Our results make a significant contribution to the study of urban bus emissions and their associated hazards, in Brazil. As emissions produced by the transport sector contain greenhouse gases (such as $\mathrm{CO}_{2}$ ) and harmful pollutants (NOx, VOC, BC, and PM), the aspects related to climate and human health should be taken into consideration, in the development of public policies. Our results suggest that a renewal of the fleet, by replacing EURO II engines by newer vehicles (EURO V or later), and introducing less-polluting buses (i.e., electrics) to the fleet, will reduce the emissions from diesel vehicles.

Supplementary Materials: The following are available online at http:/ /www.mdpi.com/2073-4433/10/3/108/s1.

Author Contributions: Conceptualization, T.N. and P.A.D.; Data curation, T.N., P.A.D., and M.V.-F.; Formal analysis, T.N., P.A.D., and M.V.-F.; Funding acquisition, M.d.F.A.; Investigation, T.N.; Methodology, T.N., P.A.D., M.V.-F., A.F., and M.d.F.A.; Resources, A.F. and M.d.F.A.; Supervision, A.F. and M.d.F.A.; Validation, T.N., A.F. and M.d.F.A.; Writing—original draft, T.N. and P.A.D.; Writing-Review and Editing, T.N., P.A.D., M.V.-F., A.F., and M.d.F.A.

Funding: This study was financed, in part, by the Coordenação de Aperfeiçoamento de Pessoal de Nível Superior-Brasil (CAPES)—Finance Code 001 and, in part, by the Fundação de Amparo à Pesquisa do Estado de São Paulo (FAPESP, Grant Nos. 15/50128-9, 16/50470-1 and 18/07848-9).

Acknowledgments: The authors acknowledge the financial support received from the FAPESP, CNPq, and the CAPES. Thiago Nogueira, would like to thank the Postgraduate Program in Meteorology at the University of São Paulo Instituto de Astronomia, Geofísica e Ciências Atmosféricas (IAG) for providing the fellowship. We are also grateful to the CETESB-Companhia Ambiental do Estado de São Paulo (Environmental Protection Agency; www. cetesb.sp.gov.br) and the ANP-Agência Nacional do Petróleo (National Petroleum Agency; www.anp.gov.br), for providing access to their data, for us to use in this study. We thank Rosana Astolfo for the valuable support during the campaigns. We also acknowledge Leila D. Martins, for kindly providing the PM data for the bus terminal in Londrina, Brazil, and Jeff Boyles, for revising the English. We also acknowledge the anonymous referees whose comments helped us to improve the overall quality of our work.

Conflicts of Interest: The authors declare no conflict of interest.

\section{References}

1. Landrigan, P.J.; Fuller, R.; Acosta, N.J.R.; Adeyi, O.; Arnold, R.; Basu, N.; Baldé, A.B.; Bertollini, R.; Bose-O'Reilly, S.; Boufford, J.I.; et al. The Lancet Commission on pollution and health. Lancet 2017, 391, 462-512. [CrossRef]

2. Bravo, M.A.; Son, J.; De Freitas, C.U.; Gouveia, N.; Bell, M.L. Air pollution and mortality in São Paulo, Brazil: Effects of multiple pollutants and analysis of susceptible populations. J. Expos. Sci. Environ. Epidemiol. 2016, 26, 150-161. [CrossRef] [PubMed]

3. Miranda, R.M.; Andrade, M.F.; Fornaro, A.; Astolfo, R.; de Andre, P.A.; Saldiva, P. Urban air pollution: A representative survey of PM(2.5) mass concentrations in six Brazilian cities. Air Qual. Atmos. Heal. 2012, 5, 63-77. [CrossRef] [PubMed]

4. Conti, V.; Orchi, S.; Valentini, M.P.; Nigro, M.; Calò, R. Design and evaluation of electric solutions for public transport. Proc. Transp. Res. Procedia 2017, 27, 117-124. [CrossRef]

5. Cepeda, M.; Schoufour, J.; Freak-Poli, R.; Koolhaas, C.M.; Dhana, K.; Bramer, W.M.; Franco, O.H. Levels of ambient air pollution according to mode of transport: A systematic review. Lancet Public Heal. 2017, 2, e23-e34. [CrossRef]

6. Lim, S.S.; Vos, T.; Flaxman, A.D.; Danaei, G.; Shibuya, K.; Adair-Rohani, H.; Amann, M.; Anderson, H.R.; Andrews, K.G.; Aryee, M.; et al. A comparative risk assessment of burden of disease and injury attributable to 67 risk factors and risk factor clusters in 21 regions, 1990-2010: A systematic analysis for the Global Burden of Disease Study 2010. Lancet 2012, 380, 2224-2260. [CrossRef]

7. Pope, C.A.; Dockery, D.W. Health Effects of Fine Particulate Air Pollution: Lines that Connect. J. Air Waste Manag. Assoc. 2006, 56, 709-742. [CrossRef] [PubMed]

8. Zhang, Q.; Jimenez, J.L.; Canagaratna, M.R.; Ulbrich, I.M.; Ng, N.L.; Worsnop, D.R.; Sun, Y. Understanding atmospheric organic aerosols via factor analysis of aerosol mass spectrometry: A review. Anal. Bioanal. Chem. 2011, 401, 3045-3067. [CrossRef] [PubMed] 
9. Donahue, N.M.; Robinson, A.L.; Pandis, S.N. Atmospheric organic particulate matter: From smoke to secondary organic aerosol. Atmos. Environ. 2009, 43, 94-106. [CrossRef]

10. UNEP/WHO. Health Effects of Black Carbon; WHO Regional Office for Europe Publications: Copenhagen, Denmark, 2012.

11. Bond, T.C.; Doherty, S.J.; Fahey, D.W.; Forster, P.M.; Berntsen, T.; Deangelo, B.J.; Flanner, M.G.; Ghan, S.; Kärcher, B.; Koch, D.; et al. Bounding the role of black carbon in the climate system: A scientific assessment. J. Geophys. Res. Atmos. 2013, 118, 5380-5552. [CrossRef]

12. Jacobson, M.Z. Strong radiative heating due to the mixing state of black carbon in atmospheric aerosols. Nature 2001, 409, 695-697. [CrossRef] [PubMed]

13. UNEP and Climate and Clean Air Coalition. Short-Lived Climate Pollutants; UNEP and Climate and Clean Air Coalition: Nairobi, Kenya, 2018.

14. Kumar, P.; Andrade, M.F.; Ynoue, R.Y.; Fornaro, A.; Freitas, E.D.; Martins, J.; Martins, L.D.; Albuquerque, T.; Zhang, Y.; Morawska, L. New directions: From biofuels to wood stoves: The modern and ancient air quality challenges in the megacity of São Paulo. Atmos. Environ. 2016, 140, 364-369. [CrossRef]

15. IBGE Estimativa da População Residente No Brasil. Diretoria de Pesquisas—Coordenação de População e Indicadores Socias. Available online: https:/ / www.ibge.gov.br/estatisticas-novoportal/sociais/populacao/ 9103-estimativas-de-populacao.html?=\&t=resultados (accessed on 12 February 2019).

16. CETESB. Qualidade do ar no estado de São Paulo 2016. Available online: http://ar.cetesb.sp.gov.br/ publicacoes-relatorios / (accessed on 1 January 2018).

17. Metro MASP Origen Destination Report. Available online: http://www.metro.sp.gov.br/metro/arquivos / mobilidade-2012/relatorio-sintese-pesquisa-mobilidade-2012.pdf (accessed on 1 January 2018).

18. Pérez-Martínez, P.J.; Andrade, M.F.; Miranda, R.M. Traffic-related air quality trends in São Paulo, Brazil. J. Geophys. Res. Atmos. 2015, 120, 6290-6304. [CrossRef]

19. Nogueira, T.; Dominutti, P.A.; Fornaro, A.; Andrade, M.F. Seasonal Trends of Formaldehyde and Acetaldehyde in the Megacity of São Paulo. Atmosphere 2017, 8, 144. [CrossRef]

20. CETESB. Emissões Veiculares no Estado de São Paulo 2016. Available online: http://cetesb.sp.gov.br/ veicular/relatorios-e-publicacoes (accessed on 1 January 2018).

21. Dominutti, P.A.; Nogueira, T.; Borbon, A.; Andrade, M.F.; Fornaro, A. One-year of NMHCs hourly observations in São Paulo megacity: Meteorological and traffic emissions effects in a large ethanol burning context. Atmos. Environ. 2016, 142, 371-382. [CrossRef]

22. EPA. Method TO-11A: Compendium of Methods for the Determination of Toxic Organic Compounds in Ambient Air Second Edition Compendium Method TO-11A Determination of Formaldehyde in Ambient Air Using Adsorbent Cartridge Followed by High Performance Liquid Chromat; Center for Environmental Research Information Office of Research and Development U.S. Environmental Protection Agency: Cincinnati, OH, USA, 1999.

23. Nogueira, T.; Dominutti, P.A.; Carvalho, L.R.F.; Fornaro, A.; Andrade, M.F. Formaldehyde and acetaldehyde measurements in urban atmosphere impacted by the use of ethanol biofuel: Metropolitan Area of Sao Paulo (MASP), 2012-2013. Fuel 2014, 134, 505-513. [CrossRef]

24. Hopke, P.K.; Xie, Y.; Raunemaa, T.; Biegalski, S.; Landsberger, S.; Maenhaut, W.; Artaxo, P.; Cohen, D. Characterization of the gent stacked filter unit pm10sampler. Aerosol Sci. Technol. 1997, 27, 726-735. [CrossRef]

25. Brito, J.; Rizzo, L.V.; Herckes, P.; Vasconcellos, P.C.; Caumo, S.E.S.; Fornaro, A.; Ynoue, R.Y.; Artaxo, P.; Andrade, M.F. Physical-chemical characterisation of the particulate matter inside two road tunnels in the São Paulo Metropolitan Area. Atmos. Chem. Phys. 2013, 13, 12199-12213. [CrossRef]

26. Gao, Y.; Nelson, E.D.; Field, M.P.; Ding, Q.; Li, H.; Sherrell, R.M.; Gigliotti, C.L.; Van Ry, D.A.; Glenn, T.R.; Eisenreich, S.J. Characterization of atmospheric trace elements on PM2.5 particulate matter over the New York-New Jersey harbor estuary. Atmos. Environ. 2002, 36, 1077-1086. [CrossRef]

27. IAG Weather Station Bulletin. Available online: http:/ / www.estacao.iag.usp.br (accessed on 2 May 2017).

28. Parrish, D.D.; Trainer, M.; Hereid, D.; Williams, E.J.; Olszyna, K.J.; Harley, R.A.; Meagher, J.F.; Fehsenfeld, F.C. Decadal change in carbon monoxide to nitrogen oxide ratio in U.S. vehicular emissions. J. Geophys. Res. 2002, 107, 4140. [CrossRef] 
29. Borbon, A.; Gilman, J.B.; Kuster, W.C.; Grand, N.; Chevaillier, S.; Colomb, A.; Dolgorouky, C.; Gros, V.; Lopez, M.; Sarda-Esteve, R.; et al. Emission ratios of anthropogenic volatile organic compounds in northern mid-latitude megacities: Observations versus emission inventories in Los Angeles and Paris. J. Geophys. Res. Atmos. 2013, 118, 2041-2057. [CrossRef]

30. ACEA. European Automobile Manufactures Association. Available online: https://www.acea.be/industrytopics / tag/category / euro-standards (accessed on 18 December 2018).

31. São Paulo city Lei $N^{\circ} 14.933$, de 5 de junho de 2009_Política de Mudança do Clima no Município de São Paulo. Available online: https:/ / leismunicipais.com.br/a/sp/s/sao-paulo/lei-ordinaria/2009/1493/14933/ lei-ordinaria-n-14933-2009-institui-a-politica-de-mudanca-do-clima-no-municipio-de-sao-paulo (accessed on 17 December 2018).

32. Dunmore, R.E.; Hopkins, J.R.; Lidster, R.T.; Lee, J.D.; Evans, M.J.; Rickard, A.R.; Lewis, A.C.; Hamilton, J.F. Diesel-related hydrocarbons can dominate gas phase reactive carbon in megacities. Atmos. Chem. Phys. 2015, 15, 9983-9996. [CrossRef]

33. Gentner, D.R.; Isaacman, G.; Worton, D.R.; Chan, A.W.H.; Dallmann, T.R.; Davis, L.; Liu, S.; Day, D.A.; Russell, L.M.; Wilson, K.R.; et al. Elucidating secondary organic aerosol from diesel and gasoline vehicles through detailed characterization of organic carbon emissions. Proc. Natl. Acad. Sci. USA 2012, 109, 18318-18323. [CrossRef] [PubMed]

34. Gentner, D.R.; Jathar, S.H.; Gordon, T.D.; Bahreini, R.; Day, D.A.; El Haddad, I.; Hayes, P.L.; Pieber, S.M.; Platt, S.M.; de Gouw, J.; et al. Review of Urban Secondary Organic Aerosol Formation from Gasoline and Diesel Motor Vehicle Emissions. Environ. Sci. Technol. 2017, 51, 1074-1093. [CrossRef] [PubMed]

35. Ait-Helal, W.; Borbon, A.; Sauvage, S.; de Gouw, J.A.; Colomb, A.; Gros, V.; Freutel, F.; Crippa, M.; Afif, C.; Baltensperger, U.; et al. Volatile and intermediate volatility organic compounds in suburban Paris: Variability, origin and importance for SOA formation. Atmos. Chem. Phys. 2014, 14, 10439-10464. [CrossRef]

36. Do, D.H.; Van Langenhove, H.; Chigbo, S.I.; Amare, A.N.; Demeestere, K.; Walgraeve, C. Exposure to volatile organic compounds: Comparison among different transportation modes. Atmos. Environ. 2014, 94, 53-62. [CrossRef]

37. Li, S.; Chen, S.; Zhu, L.; Chen, X.; Yao, C.; Shen, X. Concentrations and risk assessment of selected monoaromatic hydrocarbons in buses and bus stations of Hangzhou, China. Sci. Total Environ. 2009, 407, 2004-2011. [CrossRef] [PubMed]

38. Pinto, J.P.; Solci, M.C. Comparison of rural and urban atmospheric aldehydes in Londrina, Brazil. J. Braz. Chem. Soc. 2007, 18, 928-936. [CrossRef]

39. Pinto, J.P.; Martins, L.D.; da Silva Junior, C.R.; Sabino, F.C.; Amador, I.R.; Solci, M.C. Carbonyl concentrations from sites affected by emission from different fuels and vehicles. Atmos. Pollut. Res. 2014, 5, 404-410. [CrossRef]

40. Rodrigues, M.C.; Guarieiro, L.L.N.; Cardoso, M.P.; Souza, L.; Gisele, O.; Andrade, J.B.; Carvalho, L.S.; Da Rocha, G.O.; De Andrade, J.B. Acetaldehyde and formaldehyde concentrations from sites impacted by heavy-duty diesel vehicles and their correlation with the fuel composition: Diesel and diesel/biodiesel blends. Fuel 2012, 92, 258-263. [CrossRef]

41. Andrade, J.B.; Andrade, M.V.; Pinheiro, H.L.C. Atmospheric Levels of Formaldehyde and Acetaldehyde and their Relationship with the Vehicular Fleet Composition in Salvador, Bahia, Brazil. J. Braz. Chem. Soc. 1998, 9 , 219-223. [CrossRef]

42. Martins, L.D.; Andrade, M.F.; Ynoue, R.Y.; Albuquerque, E.L.; Tomaz, E.; Vasconcellos, P.C. Ambiental volatile organic compounds in the megacity of Sao Paulo. Quim. Nova 2008, 31, 2009-2013. [CrossRef]

43. Alvim, D.S. Estudo dos Principais Precursores de Ozônio na Região Metropolitana de São Paulo. Ph.D. Thesis, Universidade de São Paulo, São Paulo, Brazil, 2013.

44. Nogueira, T.; Souza, K.F.; Fornaro, A.; Andrade, M.F.; Carvalho, L.R.F. On-road emissions of carbonyls from vehicles powered by biofuel blends in traffic tunnels in the Metropolitan Area of Sao Paulo, Brazil. Atmos. Environ. 2015, 108, 88-97. [CrossRef]

45. Bahreini, R.; Middlebrook, A.M.; De Gouw, J.A.; Warneke, C.; Trainer, M.; Brock, C.A.; Stark, H.; Brown, S.S.; Dube, W.P.; Gilman, J.B.; et al. Gasoline emissions dominate over diesel in formation of secondary organic aerosol mass. Geophys. Res. Lett. 2012, 39. [CrossRef] 
46. Hsieh, L.-T.; Yang, H.-H.; Chen, H.-W. Ambient BTEX and MTBE in the neighborhoods of different industrial parks in Southern Taiwan. J. Hazard. Mater. 2006, 128, 106-115. [CrossRef] [PubMed]

47. Atkinson, R.; Arey, J. Atmospheric Degradation of Volatile Organic Compounds. Chem. Rev. 2003, 103, 4605-4638. [CrossRef] [PubMed]

48. Monod, A.; Sive, B.C.; Avino, P.; Chen, T.; Blake, D.R.; Sherwood, F.R. Monoaromatic compounds in ambient air of various cities: A focus on correlations between the xylenes and ethylbenzene. Atmos. Environ. 2001, 35, 135-149. [CrossRef]

49. Giubbina, F.F.; Scaramboni, C.; De Martinis, B.S.; Godoy-Silva, D.; Nogueira, R.F.P.; Campos, M.L.A.M. A simple method for simultaneous determination of acetaldehyde, acetone, methanol, and ethanol in the atmosphere and natural waters. Anal. Methods 2017, 9, 2915-2922. [CrossRef]

50. Corrêa, S.M.; Arbilla, G. Carbonyl emissions in diesel and biodiesel exhaust. Atmos. Environ. 2008, 42, 769-775. [CrossRef]

51. Guarieiro, L.L.N.; Pereira, P.A.d.P.; Torres, E.A.; da Rocha, G.O.; de Andrade, J.B. Carbonyl compounds emitted by a diesel engine fuelled with diesel and biodiesel-diesel blends: Sampling optimization and emissions profile. Atmos. Environ. 2008, 42, 8211-8218. [CrossRef]

52. Guarieiro, L.L.N.; de Souza, A.F.; Torres, E.A.; de Andrade, J.B. Emission profile of 18 carbonyl compounds, $\mathrm{CO}, \mathrm{CO} 2$, and NOxemitted by a diesel engine fuelled with diesel and ternary blends containing diesel, ethanol and biodiesel or vegetable oils. Atmos. Environ. 2009, 43, 2754-2761. [CrossRef]

53. Jimenez, J.L.; Canagaratna, M.R.; Donahue, N.M.; Prevot, A.S.; Zhang, Q.; Kroll, J.H.; DeCarlo, P.F.; Allan, J.D.; Coe, H.; Ng, N.L.; et al. Evolution of Organic Aerosols in the Atmosphere: A New Framework Connecting Measurements to Models. Science 2009, 326, 1525-1529. [CrossRef] [PubMed]

54. Donahue, N.M.; Kroll, J.H.; Pandis, S.N.; Robinson, A.L. A two-dimensional volatility basis set-Part 2: Diagnostics of organic-aerosol evolution. Atmos. Chem. Phys. 2012, 12, 615-634. [CrossRef]

55. Hamilton, J.F.; Lewis, A.C. Monoaromatic complexity in urban air and gasoline assessed using comprehensive GC and fast GC-TOF/MS. Atmos. Environ. 2003, 37, 589-602. [CrossRef]

56. Derwent, R.G.; Jenkin, M.E.; Pilling, M.J.; Carter, W.P.L.; Kaduwela, A. Reactivity scales as comparative tools for chemical mechanisms. J. Air Waste Manag. Assoc. 2010, 60, 914-924. [CrossRef] [PubMed]

57. Gilman, J.B.; Lerner, B.M.; Kuster, W.C.; Goldan, P.D.; Warneke, C.; Veres, P.R.; Roberts, J.M.; De Gouw, J.A.; Burling, I.R.; Yokelson, R.J. Biomass burning emissions and potential air quality impacts of volatile organic compounds and other trace gases from fuels common in the US. Atmos. Chem. Phys. 2015, 15, 13915-13938. [CrossRef]

58. Carter, W.P.L. Updated Maximum Incremental Reactivity Scale and Hydrocarbon Bin Reactivities for Regulatory Applications. 2010. Available online: https://www.arb.ca.gov/research/reactivity/mir09.pdf (accessed on 15 May 2017).

59. WHO. Air Quality Guidelines. Global Update 2005. Particulate Matter, Ozone, Nitrogen Dioxide and Sulfur Dioxide; WHO Regional Office for Europe Publications: Copenhagen, Denmark, 2016.

60. Andrade, M.F.; Kumar, P.; Freitas, E.D.; Ynoue, R.Y.; Martins, J.; Martins, L.D.; Nogueira, T.; Perez-Martinez, P.; Miranda, R.M.; Albuquerque, T.; et al. Air quality in the megacity of São Paulo: Evolution over the last 30 years and future perspectives. Atmos. Environ. 2017, 159, 66-82. [CrossRef]

61. Mkoma, S.L.; Da Rocha, G.O.; Regis, A.C.D.; Domingos, J.S.S.; Santos, J.V.S.; De Andrade, S.J.; Carvalho, L.S.; De Andrade, J.B. Major ions in PM2.5 and PM10 released from buses: The use of diesel/biodiesel fuels under real conditions. Fuel 2014, 115, 109-117. [CrossRef]

62. Martins, L.D.; Silva Junior, C.R.; Solci, M.C.; Pinto, J.P.; Souza, D.Z.; Vasconcellos, P.; Guarieiro, A.L.N.; Guarieiro, L.L.N.; Sousa, E.T.; De Andrade, J.B. Particle emission from heavy-duty engine fuelled with blended diesel and biodiesel. Environ. Monit. Assess. 2012, 184, 2663-2676. [CrossRef] [PubMed]

63. Pereira, G.M.; Teinilä, K.; Custódio, D.; Gomes Santos, A.; Xian, H.; Hillamo, R.; Alves, C.A.; Andrade, J.B.; Rocha, G.O.; Kumar, P.; et al. Particulate pollutants in the Brazilian city of São Paulo: 1-year investigation for the chemical composition and source apportionment. Atmos. Chem. Phys. 2017, 17, 11943-11969. [CrossRef]

64. Pérez-Martínez, P.J.; Miranda, R.M.; Nogueira, T.; Guardani, M.L.; Fornaro, A.; Ynoue, R.; Andrade, M.F. Emission factors of air pollutants from vehicles measured inside road tunnels in São Paulo: Case study comparison. Int. J. Environ. Sci. Technol. 2014, 11, 2155-2168. [CrossRef] 
65. Sánchez-Ccoyllo, O.R.; Ynoue, R.Y.; Martins, L.D.; Astolfo, R.; Miranda, R.M.; Freitas, E.D.; Borges, A.S.; Fornaro, A.; Freitas, H.; Moreira, A.; et al. Vehicular particulate matter emissions in road tunnels in Sao Paulo, Brazil. Environ. Monit. Assess. 2009, 149, 241-249. [CrossRef] [PubMed]

66. Hetem, I.G.; Andrade, M.F. Characterization of fine particulate matter emitted from the resuspension of road and pavement dust in the Metropolitan Area of São Paulo, Brazil. Atmosphere 2016, 7, 31. [CrossRef]

67. Kumar, A.; Kim, D.-S.; Omidvarbona, H.; Kuppili, S.K. Combustion Chemistry of Biodiesel for Use in Urban Transport Buses: Experiment and Modeling; Mineta National Transit Research Consortium: San Jose, CA, USA, 2014.

68. Zhang, J.; He, K.; Shi, X.; Zhao, Y. Comparison of particle emissions from an engine operating on biodiesel and petroleum diesel. Fuel 2011, 90, 2089-2097. [CrossRef]

69. Taylor, S.; McLennan, S. The geochemical evolution of the continental crust. Rev. Geophys. 1995, 33, $241-265$. [CrossRef]

(C) 2019 by the authors. Licensee MDPI, Basel, Switzerland. This article is an open access article distributed under the terms and conditions of the Creative Commons Attribution (CC BY) license (http://creativecommons.org/licenses/by/4.0/). 